to two feet in height. Where the shore presented miniature cliffs of clay capped by turf, the soil was turned over by the ice as by a ploughshare. Along the greater part of the shore-line, but especially where the shore was steep or rocky, the pressure forced the ice up into hummocky fragments. Great cracks, the edges of which were similarly thrown into hummocks, extended right across the lake at two points between Bowness and Ambleside. When the thaw set in and the ice contracted, the position of these two loci of compression was marked by wide lanes of open water, while the ice on either side was still strong enough to bear the weight of a man. Other more local evidences of compression were seen in funnel-like depressions in the ice, in some cases with a dangerous hole in the centre, though the ice surrounding the hole was so strong that a man was able without risk to reach the hat of a skater who had fallen through. Evidences of the motion of the ice in the direction of the greatest pressure was also to be seen in bent and broken piles and landing-stages. These phenomena were not to be seen where from any cause the ice did not attain to any great thickness, as, for instance, at the mouth of 'Troutbeck, where the flow of the river checked the formation of the ice.

Scarcely less remarkable than the effects of the ice-action themselves was the short time that it took for denudation to remove all traces of them.

These are the facts that I observed; and I think they may be worth putting on record, especially because the opportunities of observing them are so rare, Windermere being seldom frozen over more than three or four times in a century. Gro. Crewdson.

St. Mary's Vicarage, Windermere. September 1st, 1904.

\title{
THE DISCOVERY OF MARSUPITES IN THE CHALK OF THE CROYDON AREA.
}

Srr,-Some few weeks ago I received a letter from Messrs. Wright \& Polkinghorne (of the Battersea Field Club and Goologists' Association) to the effect that while cycling from Purley to Beddington they observed some chalk that had been thrown out while laying the sewer in one of the new roads at the top of Russell Hill.

Upon examining the chalk they were rewarded by finding plates of Marsupites. The following Thursday evening I accompanied Mr. Wright to the spot, when we found that the chalk had been put back; however, after a diligent search among the blocks on the surface, we succeeded in obtaining five or six plates, two of which were embedded in flint nodules.

The nipple-headed form of Bourgueticrinus and the pyramidated form of Echinocorys vulgaris, both characteristic fossils of the Marsupite zone, were also obtained.

The chalk is of a very soft nature, quite different to that of the other zones in the district. I spent four hours the following Saturday at excavations at a lower horizon in the hope of finding Uintacrinus, but without sucoess. I am bound to admit that the appearance of 
this zone at this spot is quite a surprise, for, standing at Russell Hill one turns to the left, where at the Haling Pit the bottom beds of the M. coranguinum beds are exposed; while immediately facing us at the Purley Junction pits (now ceased to be worked) we have the $M$. cortestudinarium zone; the dip, as revealed by the successive zones to the Chalk escarpment, being to the north and disappearing under the Tertiaries at South Croydon.

One can only account for this zone by a fold in the Chalk, as we have at Beddington, a little further south-west, the upper part of the $\boldsymbol{M}$. coranguinum beds exposed which are at a lower level, according. to ordnance datum, than Russell Hill.

Subsequent discoveries will be watched with interest by all workers in Chalk geology.

7, Champion Crescext, Lower Sydenham, S.E.

G. E. Diblex. August 29th, 1904.

\section{EQUIVALENTS OF THE LOWER CULM.}

Sir,-Mr. Jukes-Browne has pointed out to me that in my paper on the Homotaxial Equivalents of the Lower Culm I have left it uncertain what remains in North Devon as the representative of the Lower Carboniferous series, and that I might be understood to mean that there is absolutely no representative of the Carboniferous Limestone in that area. He also reminds me that Salter in 1863 mentioned the existence of soft fossiliferous shales containing Carboniferous fossils above the Pilton Beds to the north of Barnstaple, which I noted as passage beds (p. 397). He further suggests that my table of comparative succession (p.401) might be amplified thus :-

\begin{tabular}{|c|c|c|c|}
\hline \multicolumn{3}{|l|}{ DETOXSHTRE. } & Sotth-West Ireland. \\
\hline Lower Culm. & & & Posidonomya beds. \\
\hline Fremington Beds & $\ldots$ & $\ldots$ & Carboniferous shales \\
\hline Soft shales & $\ldots$ & $\ldots$ & Carboniferous slate $\}$ \\
\hline Pilton Beds $\}. .$. & $\ldots$ & $\ldots$ & Carboniferous, lower part \\
\hline Baggy Beds ... & $\ldots$ & $\ldots$ & Coomhola Beds \\
\hline
\end{tabular}

I am quite prepared to admit the possibility that the Lower Carboniferous series is represented in North Devon and in SouthWest Ireland, but at present I am not sufficiently conversant with the palæontology of the Pilton Beds to discuss the question. For its settlement, moreover, some further field-work would be required.

Stoke-on-Trext.

Whencton Hind.

September 13th, 1904.

\section{MISOEIIAINEOUS.}

Eoliths: a Chance for Collectors!-We have learnt from Mr. Benjamin Harrison, of Ightham, that, with the kind permission of Sir Mark Collett, the present owner of the property, he has recently opened a fine section in the Eolithic Drift on Terrys Lodge crest. Mr. Harrison hopes that anyone desirous of studying this drift for themselves will take advantage of this opportunity. 